\title{
The Kinocidin Interleukin-26 Shows Immediate Antimicrobial Effects Even to Multi-resistant Isolates
}

\author{
Bjoern-Thore Hansen ${ }^{\dagger}$, Gregor Maschkowitz, Rainer Podschun and Helmut Fickenscher* \\ Institute for Infection Medicine, Christian-Albrecht University of Kiel and University Hospital Schleswig-Holstein, Kiel, \\ Germany
}

OPEN ACCESS

Edited by:

Karsten Becker,

University Medicine Greifswald,

Germany

Reviewed by:

Ka-Yee Grace Choi,

University of British Columbia,

Canada

Emanuele Scala,

Solna, Karolinska Institutet, Sweden

*Correspondence:

Helmut Fickenscher

fickenscher@infmed.uni-kiel.de

tPresent Address:

Bjoern-Thore Hansen,

Medical Department II - Hematology

and Oncology,

Christian-Albrecht University of Kiel and University Hospital Schleswig-

Holstein, Kiel, Germany

Specialty section:

This article was submitted to Antimicrobials, Resistance and

Chemotherapy,

a section of the journal

Frontiers in Microbiology

Received: 11 August 2021 Accepted: 28 September 2021 Published: 18 October 2021

Citation:

Hansen B-T, Maschkowitz G,

Podschun $R$ and

Fickenscher H (2021) The Kinocidin

Interleukin-26 Shows Immediate Antimicrobial Effects Even to Multiresistant Isolates.

Front. Microbiol. 12:757215.

doi: $10.3389 /$ fmicb.2021.757215
The cationic proinflammatory cytokine Interleukin 26 (IL-26) shows antibacterial activity and inhibits the replication of cytomegalovirus and hepatitis $\mathrm{C}$ virus. This study evaluates the early microbicidal activities of IL-26 against major bacterial species including multiresistant variants and Candida albicans. Recombinant IL-26 was bacterially expressed and studied for its microbicidal effects in culture. We show that IL-26 has strong 90\% bactericidal activities against Enterococcus faecalis, Enterococcus faecium, Staphylococcus aureus, and Acinetobacter baumannii. Similarly, IL-26 sensitivity was also detectable in vancomycin-resistant Enterococcus species, methicillin-resistant $S$. aureus, and carbapenem-resistant $A$. baumannii clinical isolates. Additionally, a significant, albeit weak fungicidal effect against Candida albicans was observed. Activities against Escherichia coli, Klebsiella pneumoniae, and Pseudomonas aeruginosa were not detectable. The proinflammatory cytokine and kinocidin IL-26 shows strong bactericidal activities against A. baumannii and, almost selectively, against Gram-positive bacteria.

Keywords: kinocidin, interleukin-26, antimicrobial peptide, bactericidal activity, multi-resistant bacteria

\section{INTRODUCTION}

The highly cationic proinflammatory cytokine Interleukin 26 (IL-26) is a member of the IL-10 family of cytokines. IL-26 is produced by different cell types, such as activated T cells or inflammatory fibroblasts, and stimulates the production of other proinflammatory cytokines in various cell types (Knappe et al., 2000; Fickenscher et al., 2002; Hör et al., 2004; Corvaisier et al., 2012; Braum et al., 2013; Che et al., 2014, 2017; Larochette et al., 2019). IL-26 uses a specific, heterodimeric cytokine receptor consisting of IL-20R1 and IL-10R2 on epithelial cells, whereas its action on other cell types is independent of this receptor (Hör et al., 2004; Sheikh et al., 2004; Corvaisier et al., 2012). Accordingly, elevated IL-26 levels were found in inflamed tissues or plasma of patients with different inflammatory diseases (Dambacher et al., 2009; Corvaisier et al., 2012; Che et al., 2014, 2017; Miot et al., 2014; Meller et al., 2015; Konradsen et al., 2016; Fujii et al., 2017; Heftdal et al., 2017; Poli et al., 2017; Caiazzo et al., 2018; Larochette et al., 2019; Scala et al., 2019; Brilland et al., 2021). Moreover, IL-26 inhibits cytomegalovirus and hepatitis $\mathrm{C}$ virus replication and promotes the replication of vesicular stomatitis virus (Braum et al., 2013; Miot et al., 2014). IL-26 is a highly cationic protein with amphipathic helices, which are typical for cationic cell-penetrating peptides (Knappe et al., 2000; Meller et al., 2015). IL-26 shares structural similarity with antimicrobial peptides (AMP) 
and bacteriostatic activities of IL-26 against both Gram-positive and Gram-negative bacteria have been demonstrated (Meller et al., 2015; Agak et al., 2018; Woetmann et al., 2018; Scala et al., 2019). Recombinant IL-26 has a molecular weight of $19 \mathrm{kDa}$ and the formation of dimers, oligomers, and multimers has been described. Since IL-26 combines cytokine functions with antimicrobial activities, it belongs to the group of kinocidins (Yount et al., 2004; Yeaman et al., 2007; Larochette et al., 2019). This project targets the rapid, microbicidal activities of IL-26.

\section{MATERIALS AND METHODS}

\section{Production of Recombinant Protein}

Induction of IL-26 protein synthesis was achieved in Escherichia coli strain XL1blue, which is capable of producing IL-26 in inclusion bodies, by adding $1 \mathrm{mM}$ isopropyl $\beta$-D-1thiogalactopyranoside and cultivation for $6 \mathrm{~h}$ (Knappe et al., 2000; Hör et al., 2004). First, the bacteria were disrupted mechanically in $6 \mathrm{M}$ guanidinium chloride with $0.1 \mathrm{M} \mathrm{NaH}_{2} \mathrm{PO}_{4}$, $0.01 \mathrm{M}$ Tris, and $100 \mathrm{mM} \beta$-mercaptoethanol. Bacterial debris was removed by centrifugation for $30 \mathrm{~min}$ at $8,873 \times \mathrm{g}$ and by sterile filtration. Nickel-chelate affinity chromatography was used for protein purification under denaturing conditions $(\mathrm{Ni}$ Sepharose 6 Fast Flow, GE Healthcare Life Sciences, Buckinghamshire, UK). Particle-bound IL-26 was eluted under increasing imidazole concentrations $(40 \mathrm{mM}, 500 \mathrm{mM}$, and $600 \mathrm{mM}$ ). Eluate fractions were tested for $19 \mathrm{kDa}$ bands in Coomassie-stained protein gels. Renaturation of relevant eluate fractions was achieved by dialysis for $24 \mathrm{~h}$ twice, at $4^{\circ} \mathrm{C}(20 \mathrm{mM}$ HEPES, $1 \mathrm{mM} \mathrm{MgCl} 2,20 \mathrm{mM} \mathrm{KCl,} 0.1 \mathrm{mM}$ EDTA, $1 \%$ glycerol, $1 \mathrm{mM}$ oxidated glutathione, and $5 \mathrm{mM}$ reduced glutathione, $\mathrm{pH}$ 8.0).

\section{Testing IL-26 for Functionality}

The physiological STAT3 phosphorylation activity of the newly produced IL-26 was tested with the human colon carcinoma cell line COLO-205. IL-26 $(5 \mu \mathrm{g} / \mathrm{ml})$ was added for $45 \mathrm{~min}$ at $37^{\circ} \mathrm{C}$. Cell lysates were separated on protein gels and Western blots were probed with anti-phospho-STAT3 and anti-STAT3 antibodies (anti-phospho-Tyr705 STAT3, \#9131, rabbit; antiSTAT3, \#9132, rabbit) and horseradish peroxidase-conjugated anti-rabbit IgG antibodies (\#7074, goat, Cell Signaling Technology, Beverly, United States) as secondary reagent. Signals were detected by chemiluminescence (Figure 1) using a chargedcoupled device camera (LAS-3000, Fujifilm, Tokio, Japan). If phospho-STAT3 bands were detectable, the respective IL-26 fraction was considered biologically active.

\section{Testing for Antimicrobial Activity}

Bacteria and C. albicans were initially grown on Columbia sheep blood agar at $37^{\circ} \mathrm{C}$ overnight and then for $20 \mathrm{~h}$ at $37^{\circ} \mathrm{C}$ in $10 \mathrm{ml}$ tryptic soy broth (TSB) medium with $10 \mathrm{mM} \mathrm{NaCl}$. Then, $50 \mu \mathrm{l}$ of the culture was added to $10 \mathrm{ml}$ of TSB/10 mM $\mathrm{NaCl}$ medium and incubated for $3 \mathrm{~h}$ at $37^{\circ} \mathrm{C}$ for reaching the logarithmic phase of growth and the optical density at $600 \mathrm{~nm}$ was determined. We diluted the culture with $10 \mathrm{mM} \mathrm{NaCl}$ to reach target concentrations of $10^{5} \mathrm{CFU} / \mathrm{ml}$. Next, $100 \mu \mathrm{l}$ of the microbial suspension was added to $100 \mu \mathrm{l}$ of different concentrated IL-26 solutions $(100,30,10,3$, and $1 \mu \mathrm{g} / \mathrm{ml})$ to achieve final IL-26 concentrations in the wells of $50,15,5,1.5$, and $0.5 \mu \mathrm{g} / \mathrm{ml}$. We always ran negative controls with pure dialysis buffer instead of the IL-26 solution, as well as positive controls with bacteria that were previously shown to be highly sensitive to IL-26, when species with low or lacking IL-26 sensitivity were examined.

Immediately after the start of the treatment, and after 1 , 2,3 , and $4 \mathrm{~h}, 20 \mu \mathrm{l}$ from each culture was sampled and diluted in a $0.85 \% \mathrm{NaCl}$ solution and $100 \mu \mathrm{l}$ of that dilution was pipetted on two lysogeny broth (LB) agar plates each. The plates were incubated overnight at $37^{\circ} \mathrm{C}$ and the colonies were counted. The numbers of colony forming units per milliliter $(\mathrm{CFU} / \mathrm{ml})$ were calculated after averaging of the counting results of the two separate plates in consideration of the dilution factor. Totally, 15,000 LB agar plates were plated by hand for 66 independent experiments.

\section{Statistical Evaluation}

Statistical evaluation was performed with GraphPad PRISM 8 (GraphPad Software, Inc., San Diego, CA, United States). Values of $p$ were determined by using the independent two-sample $t$-test. We used linear regression for calculating the minimal concentration for $90 \%$ bactericidal or fungicidal effects $\left(\mathrm{MBC}_{90} /\right.$ $\mathrm{MFC}_{90}$ ), respectively, the lethal dose or concentration for $90 \%$ killing $\left(\mathrm{LD}_{90} / \mathrm{LC}_{90}\right)$. All results of this study are given as $\mathrm{MBC}_{90} /$ $\mathrm{MFC}_{90}$, even though the use of $\mathrm{LD}_{90} / \mathrm{LC}_{90}$ is also common in AMP research. The use of the terms MBC/MFC may be more precise from a microbiological point of view. Results with values of $p \leq 0.05$ were rated significant. As far as not given in numbers, significances are labeled as followed: ${ }^{\star} p \leq 0.05$; ${ }^{* *} p \leq 0.01 ;{ }^{* *} p \leq 0.001$; and ${ }^{* * *} p \leq 0.0001$, ns $=$ not significant.

$86 \mathrm{kDa}-\mathrm{kD}-\mathrm{k}$
$79 \mathrm{kDa}-$




\section{RESULTS}

IL-26 was tested for bactericidal activities against different Gram-positive and Gram-negative strains of different antibiotic resistance phenotypes, as well as for fungicidal activities against C. albicans. All experiments were performed with a standardized protocol and were highly reproducible. The anti-infective activities were analyzed quantitatively for the minimal concentration for $90 \%$ bactericidal or fungicidal effects $\left(\mathrm{MBC}_{90} / \mathrm{MFC}_{90}\right)$.

\section{Activity Against Enterococci}

Directly after adding $50 \mu \mathrm{g} / \mathrm{ml}$ IL-26 to Enterococcus faecalis ATCC 29212 cultures, an immediate and highly significant $(p \leq 0.0001)$ reduction of the number of colony forming units (CFU) of approximately $98.4 \%$ was detected. After $1 \mathrm{~h}$, significant effects were found from $5 \mu \mathrm{g} / \mathrm{ml}$ on. Complete eradication of all bacteria was reached at $50 \mu \mathrm{g} / \mathrm{ml}$ IL-26, after incubation for at least $1 \mathrm{~h}$. The CFU numbers after 2, 3, and $4 \mathrm{~h}$ of incubation were reduced by $97.3,92.3$, and $96.1 \%$ at $15 \mu \mathrm{g} \mathrm{ml}$ IL-26 (Figure 2A).

Similar to the antibiotic-sensitive type strain, a vancomycinresistant clinical isolate of $E$. faecalis showed an instant significant effect. After $1 \mathrm{~h}$, significant CFU number reductions were found starting from $0.5 \mu \mathrm{g} / \mathrm{ml}$, whereas the strongest results were observed at $15 \mu \mathrm{g} / \mathrm{ml}$ (reduction of $72.5 \%$ ) and $50 \mu \mathrm{g} / \mathrm{ml}(99.6 \%)$. The reduction levels stayed constant over time. After $4 \mathrm{~h}$, the incubation with $50 \mu \mathrm{g} / \mathrm{ml}$ IL-26 resulted in a highly significant decline of CFU numbers by $99.95 \%$ (Figure 2B).

Likewise, Enterococcus faecium ATCC 6057 showed a prompt significant drop of the CFU numbers at $15 \mu \mathrm{g} / \mathrm{ml}$ by $70.6 \%$ and at $50 \mu \mathrm{g} / \mathrm{ml}$ by $99.5 \%$. This effect increased, when the incubation was performed for $1 \mathrm{~h}$. Reduction values were $81.3 \%$ for $5 \mu \mathrm{g} /$ $\mathrm{ml}, 99.96 \%$ for $15 \mu \mathrm{g} / \mathrm{ml}$, and a complete killing of all bacteria was achieved for $50 \mu \mathrm{g} / \mathrm{ml}$. After 2 and $4 \mathrm{~h}$, complete eradications were reached at $15 \mu \mathrm{g} / \mathrm{ml}$. At $3 \mathrm{~h}$, reductions amounted to $99.98 \%$ for $15 \mu \mathrm{g} / \mathrm{ml}$ and $100 \%$ for $50 \mu \mathrm{g} / \mathrm{ml}$ (Figure 2C).

Subsequently, we checked for IL-26 sensitivity of vancomycinresistant E. faecium DSM 17050 (Deutsche Sammlung von Mikroorganismen, German Collection of Microorganisms, Hannover, Germany). Again, a significant immediate decline by $99.1 \%$ was achieved at $50 \mu \mathrm{g} / \mathrm{ml} \mathrm{IL}-26$. After $1 \mathrm{~h}$, complete eradication of all bacteria was reached at $50 \mu \mathrm{g} / \mathrm{ml}$, whereas $99.89 \%$ were killed at $15 \mu \mathrm{g} / \mathrm{ml}$. These effects were stable $( \pm 0.2 \%$ at $15 \mu \mathrm{g} / \mathrm{ml})$ for 2,3 , and $4 \mathrm{~h}$ incubation time. After $3 \mathrm{~h}$, an additional significant but weaker effect was found at $5 \mu \mathrm{g} / \mathrm{ml}$, which lost its significance after $4 \mathrm{~h}$ (Figures 2D, 3).

\section{Activity Against Staphylococcus aureus}

In the case of $S$. aureus ATCC 6538, we found an instant reduction of the CFU numbers of approximately $23.2 \%$ at $50 \mu \mathrm{g} / \mathrm{ml} \mathrm{IL-26}(p=0.37)$, which increased after $1 \mathrm{~h}$ to a highly significant reduction by $94.6 \%(p<0.0001)$. Further increments were achieved upon ongoing incubation. CFU reductions at $50 \mu \mathrm{g} / \mathrm{ml}$ reached 95.6, 98.0, and $93.4 \%$ after 2, 3, and $4 \mathrm{~h}$. After 2 and $3 \mathrm{~h}$, significant but weak effects were detectable at $15 \mu \mathrm{g} / \mathrm{ml}$ (Figure 2E).
In contrast to the antibiotic-sensitive $S$. aureus ATCC 6538, the MRSA strain ATCC 33593 showed highly significant CFU reductions immediately after adding IL-26 to the cultures at $15 \mu \mathrm{g} / \mathrm{ml}$ with a decline by $90.1 \%$ and at $50 \mu \mathrm{g} / \mathrm{ml}$ by 99.3\%. These effects increased after $1 \mathrm{~h}$ with CFU reductions by $53.3 \%$ at $1.5 \mu \mathrm{g} / \mathrm{ml}, 81.4 \%$ at $5 \mu \mathrm{g} / \mathrm{ml}, 99.8 \%$ at $15 \mu \mathrm{g} / \mathrm{ml}$, and a complete eradication of all bacteria at $50 \mu \mathrm{g} / \mathrm{ml}$. After $2 \mathrm{~h}$, the effects at $5 \mu \mathrm{g} / \mathrm{ml}$ and $15 \mu \mathrm{g} / \mathrm{ml}$ were stable $( \pm 0.1 \%)$ and complete killing at $50 \mu \mathrm{g} / \mathrm{ml}$ was still achieved. When incubating for $3 \mathrm{~h}$, reductions were found at $0.5 \mu \mathrm{g} / \mathrm{ml}(33.5 \%)$, $1.5 \mu \mathrm{g} / \mathrm{ml}(36.5 \%), 5 \mu \mathrm{g} / \mathrm{ml}(83.9 \%), 15 \mu \mathrm{g} / \mathrm{ml}(99.8 \%)$, and $50 \mu \mathrm{g} / \mathrm{ml}(100 \%)$, of which all were significant, besides at $1.5 \mu \mathrm{g} / \mathrm{ml}$. Last, after $4 \mathrm{~h}$, declines by $63.6 \%$ at $5 \mu \mathrm{g} / \mathrm{ml}, 98.6 \%$ at $15 \mu \mathrm{g} / \mathrm{ml}$, and complete eradication at $50 \mu \mathrm{g} / \mathrm{ml}$ were observed (Figure 2F).

\section{Activity Against Multi-resistant Gram-positive Bacteria}

The $\mathrm{MBC}_{90}$ for immediate effects ranged from $38.5 \mu \mathrm{g} / \mathrm{ml}$ (MRSA ATCC 33593 ) to $57.5 \mu \mathrm{g} / \mathrm{ml}$ (vancomycin-resistant E. faecalis), except for the methicillin-sensitive $S$. aureus ATCC 6538 with an unusually high $\mathrm{MBC}_{90}$ of $136 \mu \mathrm{g} / \mathrm{ml}$. Two groups of similar $\mathrm{MBC}_{90}$ ranges were defined. In the first group, E. faecalis ATCC 29212, E. faecium ATCC 6057, vancomycin-resistant E. faecium ATCC 17050, and MRSA ATCC 33593 had average $\mathrm{MBC}_{90}$ values between $12.5 \mu \mathrm{g} / \mathrm{ml}$ and $13.4 \mu \mathrm{g} / \mathrm{ml} \mathrm{IL-26}$ for 1 to $3 \mathrm{~h}$ and $19.3 \mu \mathrm{g} / \mathrm{ml}$ after $4 \mathrm{~h}$. In the other group, the average $\mathrm{MBC}_{90}$ for 1 to $4 \mathrm{~h}$ for vancomycin-resistant E. faecalis and methicillin-sensitive $S$. aureus ATCC 6538 ranged between $43.7 \mu \mathrm{g} / \mathrm{ml}$ and $45.5 \mu \mathrm{g} / \mathrm{ml}$ (Table 1). Hence, we were able to show for the first time that IL-26 functions as a highly active bactericidal agent against different Gram-positive bacteria. These effects are independent of the antibiotic resistance phenotypes since multi-resistant strains of $S$. aureus, E. faecalis, and E. faecium were as sensitive as or even more sensitive than their antibiotic-sensitive counterparts.

\section{Activity Against Acinetobacter baumannii}

Concerning Gram-negative species, we first tested A. baumannii ATCC 19606. Similar to all tested Gram-positive bacteria, an initial albeit weak CFU reduction was observed. After $1 \mathrm{~h}$ of incubation, a highly significant decline of $99.8 \%$ was detected at $50 \mu \mathrm{g} / \mathrm{ml}$ IL-26 and stayed constant for $4 \mathrm{~h}( \pm 0.3 \%)$. Additionally, we found a $50 \%$ non-significant reduction at $15 \mu \mathrm{g} / \mathrm{ml}$ (Figure 2G).

Moreover, two highly resistant $A$. baumannii $\mathrm{CR}$ isolates were analyzed, which solely were sensitive for colistin. The first one was isolated in 2014 from a patient from a local outbreak at the University Hospital Schleswig-Holstein in Kiel, Germany. An immediate reduction was not observed but, again, highly significant CFU reductions were measureable at 1,2 , 3 , and $4 \mathrm{~h}(99.4,99.3,99.7$, and $99.7 \%)$ at IL-26 concentrations of $50 \mu \mathrm{g} / \mathrm{ml}$ (Figure $2 \mathbf{H}$ ). The other A. baumannii CR isolate resulted from a patient from 2018 with previous hospitalization in a country with high prevalence of colonization with CR A. baumannii. Here, we detected a significant immediate 




reduction of $31.7 \%$ at $50 \mu \mathrm{g} / \mathrm{ml}$ IL-26. Furthermore, weaker and non-significant reductions were detectable at $0.5 \mu \mathrm{g} / \mathrm{ml}$, $5 \mu \mathrm{g} / \mathrm{ml}$, and $15 \mu \mathrm{g} / \mathrm{ml}$. After $1 \mathrm{~h}$, the decline of the CFU count at $50 \mu \mathrm{g} / \mathrm{ml} \mathrm{IL-26}$ was $98.7 \%$ and increased in the course of the experiments to $99.4 \%(2 \mathrm{~h}), 99.8 \%(3 \mathrm{~h})$, and $99.6 \%(4 \mathrm{~h}$; Figure 2I). The mean $\mathrm{MBC}_{90}$ values for the three A. baumannii 




strains (ATCC 19606, 2014, 2018) were $374.6 \mu \mathrm{g} / \mathrm{ml}$ for $0 \mathrm{~h}$, $46.91 \mu \mathrm{g} / \mathrm{ml}$ for $1 \mathrm{~h}, 48.09 \mu \mathrm{g} / \mathrm{ml}$ for $2 \mathrm{~h}, 46.8 \mu \mathrm{g} / \mathrm{ml}$ for $3 \mathrm{~h}$, and $47.22 \mu \mathrm{g} / \mathrm{ml}$ for $4 \mathrm{~h}$ (Table 1 ).

A. baumannii was the only tested Gram-negative species with IL-26 sensitivity. In contrast, we were unable to detect any antimicrobial effects against E. coli ATCC 11775 , K. pneumoniae ATCC 4352, or $P$. aeruginosa ATCC 27853 for IL-26 concentrations up to $50 \mu \mathrm{g} / \mathrm{ml}$ (Figures 2J-L).

\section{Activity Against Candida albicans}

Last, the sensitivity of C. albicans ATCC 24433 against IL-26 was investigated. Immediate effects were not detected at up to $50 \mu \mathrm{g} / \mathrm{ml} \mathrm{IL-26.} \mathrm{The} \mathrm{CFU} \mathrm{reduction} \mathrm{values} \mathrm{at} 50 \mu \mathrm{g} / \mathrm{ml} \mathrm{IL-26}$ were $29 \%$ after $1 \mathrm{~h}$ (non-significant), $67.5 \%$ after $2 \mathrm{~h}, 58.2 \%$ after $3 \mathrm{~h}$, and $78.5 \%$ after $4 \mathrm{~h}$ (all significant). The $\mathrm{MFC}_{90}$ values ranged from 54.7 to $81.41 \mu \mathrm{g} / \mathrm{ml}$ (Table 1). Hence, we were able to show a reproducible and significant, albeit weak fungicidal activity of IL-26 against C. albicans.

Thus, the cytokine IL-26 with its proinflammatory, bactericidal, antiviral, and fungicidal activities can be attributed to the group of kinocidins which was defined for cytokines with direct antimicrobial effects, such as human mammalian platelet factor 4 (hPF-4; Yount et al., 2004; Yeaman et al., 2007; Larochette et al., 2019).

\section{DISCUSSION}

Whereas all tested Gram-positive bacterial strains were highly sensitive to IL-26, we observed a remarkable difference between A. baumannii strains and all other Gram-negatives (enterobacteria and $P$. aeruginosa). Thus, the questions arise why all other Gram-negative species are non-sensitive for IL-26 and what the essential factor is for the sensitivity of A. baumannii. The lipopolysaccharides (LPS) and especially the O-antigen, which is the outer chain of the LPS, are two known factors for AMP resistance in Gram-negative bacteria (Silhavy et al., 2010; Joo et al., 2016). Acinetobacter species are unable to produce complete LPS due to the absence of $\mathrm{O}$-antigen-ligase activity and the lipooligosaccharide (LOS) core, the lipid A, is remaining (Weber et al., 2016). Thus, O-antigen might be responsible for the IL-26 resistance of Gram-negative species.

Concerning the mode of IL-26 action, the direct interaction with the bacterial cell membrane including pore formation seems likely, similarly to other AMP (Patel and Akhtar, 2017). Due to its high cationic charge, IL-26 binds to glycosaminoglycans of the surface of eukaryotic cells (Hör et al., 2004), as well as to LPS and lipoteichoic acid of the surface of bacteria (Meller et al., 2015). Based on electron micrographs of P. aeruginosa ATCC 27853, bleb-formation followed by membrane disruption was described as the mode of IL-26 action (Meller et al., 2015). However, this needs to be interpreted with caution, since exactly the same $P$. aeruginosa strain has been classified as IL-26 resistant in this study.

The initial publication concerning antimicrobial activities of IL-26 described bacteriostatic effects at $50 \%$ level for 5 to $10 \mu \mathrm{M}$ IL-26 against $P$. aeruginosa ATCC 27853, E. coli ATCC 11775, K. pneumoniae O1:K2, and S. aureus ATCC 6538 but no detectable effects against E. faecalis ATCC 29212 and C. albicans ATCC 24433 (Meller et al., 2015). In contrast, our study was able to demonstrate strong bactericidal activities at $90 \%$ level against the Gram-positive strains E. faecalis ATCC 29212, vancomycin-resistant E. faecalis, E. faecium ATCC 6057, vancomycin-resistant E. faecium DSM 17050, S. aureus ATCC 6538, and MRSA ATCC 33593. Furthermore, we were able to show strong effects on naturally $\mathrm{O}$-antigen deficient A. baumannii independently of carbapenem 
TABLE 1 | MBC $_{90} / \mathrm{MFC}_{90}$ values for all IL-26-sensitive species.

\begin{tabular}{|c|c|c|c|c|c|c|}
\hline \multirow{2}{*}{ Species } & \multicolumn{5}{|c|}{$\mathrm{MBC}_{90} / \mathrm{MFC}_{90}$} & \multirow[b]{2}{*}{$\boldsymbol{h}$} \\
\hline & 0 & 1 & 2 & 3 & 4 & \\
\hline E. faecalis, ATCC 29212 & 45.58 & 14.16 & 14.23 & 14.40 & 14.51 & $\mu \mathrm{g} / \mathrm{m}$ \\
\hline E. faecalis (VRE) & 54.48 & 40.04 & 41.59 & 40.67 & 42.38 & $\mu \mathrm{g} / \mathrm{m}$ \\
\hline E. faecium, ATCC 6057 & 46.75 & 11.72 & 13.58 & 13.79 & 13.41 & $\mu \mathrm{g} / \mathrm{m}$ \\
\hline E. faecium (VRE), DSM 17050 & 42.84 & 12.94 & 14.02 & 12.75 & 13.02 & $\mu \mathrm{g} / \mathrm{m}$ \\
\hline S. aureus, ATCC 6538 & 136.00 & 47.31 & 46.19 & 47.15 & 48.54 & $\mu \mathrm{g} / \mathrm{m}$ \\
\hline S. aureus (MRSA), ATCC 33593 & 38.48 & 11.51 & 11.87 & 11.42 & 36.20 & $\mu \mathrm{g} / \mathrm{m}$ \\
\hline A. baumannii, ATCC 11775 & 149.40 & 46.12 & 48.42 & 46.21 & 43.36 & $\mu \mathrm{g} / \mathrm{m}$ \\
\hline A. baumannii (CR), 2014 & 832.10 & 47.15 & 47.90 & 48.18 & 49.97 & $\mu \mathrm{g} / \mathrm{m}$ \\
\hline A. baumannii (CR), 2018 & 142.30 & 47.46 & 47.96 & 46.02 & 48.32 & $\mu \mathrm{g} / \mathrm{m}$ \\
\hline C. albicans, ATCC 24433 & - & - & 81.41 & 77.77 & 54.74 & $\mu \mathrm{g} / \mathrm{m}$ \\
\hline
\end{tabular}

Data calculated by linear regression; $n=3$ per species; "-"= not calculable.

resistance, and weak effects on C. albicans ATCC 24433 after at least $2 \mathrm{~h}$ of incubation. Effects against E. coli ATCC 11775, K. pneumoniae ATCC 4352, and P. aeruginosa ATCC 27853 were not detectable. This goes in line with a study in which IL-26 exhibited bacteriostatic activities against S. aureus ATCC 6538 but not against $P$. aeruginosa ATCC 27853 (Scala et al., 2019). Another published study did not show immediate effects for S. aureus and E. coli; however, bactericidal effects were detected after 4 to $24 \mathrm{~h}$ of incubation with $1 \mu \mathrm{g} / \mathrm{ml}$ IL-26 (Agak et al., 2018). In a third publication, an activity against biofilm formation of $S$. aureus was detected which was more pronounced for IL-26 than for the AMP LL-37 (Woetmann et al., 2018). Regarding Mycobacteria (M.) IL-26 has been shown to inhibit growth and reduce viability of $M$. leprae and $M$. tuberculosis in axenic cultures as well as within macrophages, probably by inducing lysis by bleb-formation after interaction with lipoarabinomannan (Dang et al., 2019; Hawerkamp et al., 2020).

The reason for these functional differences might be due to the different sources and qualities of commercially available IL-26 (Knappe et al., 2000; Hör et al., 2004). In order to ensure high quality and functionality, we used self-produced IL-26 which was functionally tested for STAT3 activation in a colonic carcinoma cell line. Moreover, molar concentrations are difficult to interpret since IL-26 occurs as monomers, dimers, oligomers, and even multimers (Knappe et al., 2000; Fickenscher et al., 2002; Meller et al., 2015).

Concerning the raising relevance of antibiotic-resistant bacteria, AMP have come under scrutiny, especially due to the lack of resistance development, even though they have always been present during evolution (Zasloff, 2002; Gallo and Hooper, 2012). Besides potential pharmacotechnological and galenic challenges in the production of this instable kinocidin, additional immunologic effects of the proinflammatory IL-26 need to be considered in the case of a possible therapeutic application. In published experiments, IL-26 or LL-37 was applied nasally in mice after nasal application of bacteria and a certain reduction of the CFU number (factor 10-100) was seen (Meller et al., 2015). However, these experiments were performed with $K$. pneumoniae, which was classified as IL-26 resistant in this study.

Compared to other AMP, which usually have a broad activity spectrum against Gram-positive and Gram-negative bacteria, protozoa, and fungi (Ebbensgaard et al., 2015), IL-26 has its main target in Gram-positive bacteria, which has not yet been described for other AMP. Thus, IL-26 is a unique member of the family of cationic AMP. In summary, we showed for the first time that IL-26 is a proinflammatory kinocidin with bactericidal and fungicidal activities, which is also active against $A$. baumannii and C. albicans and kills Gram-positive bacteria almost selectively.

\section{DATA AVAILABILITY STATEMENT}

The original contributions presented in the study are included in the article, further inquiries can be directed to the corresponding author.

\section{AUTHOR CONTRIBUTIONS}

BTH wrote the manuscript, designed and performed the experiments, and prepared the figures and tables. GM contributed to the experiments, reviewed and edited the manuscript, and supervised the project. RP gave advice for the experimental design and reviewed and edited the manuscript. HF wrote the manuscript, gave advice for the experimental design, and supervised the project. All authors contributed to the article and approved the submitted version.

\section{FUNDING}

This project was supported in part by the Excellence Clusters Inflammation at Interfaces and Precision Medicine at Kiel and funded in part by the Deutsche Forschungsgemeinschaft (DFG, German Research Foundation) - project number 413490537 within the Kiel Clinician Scientist Programme in Evolutionary Medicine. We acknowledge financial support by the state Schleswig-Holstein within the funding programme Open Access Publikationsfonds.

\section{ACKNOWLEDGMENTS}

We thank Andrea Hölzgen and Petra Krüger for expert technical assistance. 


\section{REFERENCES}

Agak, G. W., Kao, S., Ouyang, K., Qin, M., Moon, D., Butt, A., et al. (2018). Phenotype and antimicrobial activity of Th17 cells induced by Propionibacterium acnes strains associated with healthy and acne skin. J. Invest. Dermatol. 138, 316-324. doi: 10.1016/j.jid.2017.07.842

Braum, O., Klages, M., and Fickenscher, H. (2013). The cationic cytokine IL-26 differentially modulates virus infection in culture. PLoS One 8:e70281. doi: 10.1371/journal.pone.0070281

Brilland, B., Bach-Bunner, M., Gomes, C. N., Larochette, V., Foucher, E., Plaisance, M., et al. (2021). Serum interleukin-26 is a new biomarker for disease activity assessment in systemic Lupus erythematosus. Front. Immunol. 12:663192. doi: 10.3389/fimmu.2021.663192

Caiazzo, G., Di Caprio, R., Lembo, S., Raimondo, A., Scala, E., Patruno, C., et al. (2018). IL-26 in allergic contact dermatitis: Resource in a state of readiness. Exp. Dermatol. 27, 681-684. doi: 10.1111/exd.13521

Che, K. F., Kaarteenaho, R., Lappi-Blanco, E., Levänen, B., Sun, J., Wheelock, Å., et al. (2017). Interleukin-26 production in human primary bronchial epithelial cells in response to viral stimulation: modulation by Th17 cytokines. Mol. Med. 23, 247-257. doi: 10.2119/molmed.2016.00064

Che, K. F., Tengvall, S., Levänen, B., Silverpil, E., Smith, M. E., Awad, M., et al. (2014). Interleukin-26 in antibacterial host defense of human lungs. Effects on neutrophil mobilization. Am. J. Respir. Crit. Care Med. 190, 1022-1031. doi: 10.1164/rccm.201404-0689OC

Corvaisier, M., Delneste, Y., Jeanvoine, H., Preisser, L., Blanchard, S., Garo, E., et al. (2012). IL-26 is overexpressed in rheumatoid arthritis and induces proinflammatory cytokine production and Th17 cell generation. PLoS Biol. 10:e1001395. doi: 10.1371/annotation/22e63f1f-1a6e-4d53-8d33-06527d9a1dd4

Dambacher, J., Beigel, F., Zitzmann, K., De Toni, E. N., Göke, B., Diepolder, H. M., et al. (2009). The role of the novel Th17 cytokine IL-26 in intestinal inflammation. Gut 58, 1207-1217. doi: 10.1136/gut.2007.130112

Dang, A. T., Teles, R. M., Weiss, D. I., Parvatiyar, K., Sarno, E. N., Ochoa, M. T., et al. (2019). IL-26 contributes to host defense against intracellular bacteria. J. Clin. Invest. 129, 1926-1939. doi: 10.1172/JCI99550

Ebbensgaard, A., Mordhorst, H., Overgaard, M. T., Nielsen, C. G., Aarestrup, F. M., and Hansen, E. B. (2015). Comparative evaluation of the antimicrobial activity of different antimicrobial peptides against a range of pathogenic bacteria. PLoS One 10:e0144611. doi: 10.1371/journal.pone.0144611

Fickenscher, H., Hör, S., Küpers, H., Knappe, A., Wittmann, S., and Sticht, H. (2002). The interleukin-10 family of cytokines. Trends Immunol. 23, 89-96. doi: 10.1016/S1471-4906(01)02149-4

Fujii, M., Nishida, A., Imaeda, H., Ohno, M., Nishino, K., Sakai, S., et al. (2017). Expression of Interleukin-26 is upregulated in inflammatory bowel disease. World J. Gastroenterol. 23, 5519-5529. doi: 10.3748/wjg.v23. i30.5519

Gallo, R. L., and Hooper, L. (2012). Epithelial antimicrobial defence of the skin and intestine. Nat. Rev. Immunol. 12, 503-516. doi: 10.1038/nri3228

Hawerkamp, H. C., van Geelen, L., Korte, J., Di Domizio, J., Swidergall, M., Momin, A. A., et al. (2020). Interleukin-26 activates macrophages and facilitates killing of Mycobacterium tuberculosis. Sci. Rep. 10, 171-178. doi: 10.1038/s41598-020-73989-y

Heftdal, L. D., Andersen, T., Jaehger, D., Woetmann, A., Østgård, R., Kenngott, E. E., et al. (2017). Synovial cell production of IL-26 induces bone mineralization in spondyloarthritis. J. Mol. Med. 95, 779-787. doi: 10.1007/s00109-017-1528-2

Hör, S., Pirzer, H., Dumoutier, L., Bauer, F., Wittmann, S., Sticht, H., et al. (2004). The T-cell lymphokine interleukin-26 targets epithelial cells through the interleukin-20 receptor 1 and interleukin-10 receptor 2 chains. J. Biol. Chem. 279, 33343-33351. doi: 10.1074/jbc.M405000200

Joo, H. S., Fu, C. I., and Otto, M. (2016). Bacterial strategies of resistance to antimicrobial peptides. Philos. Trans. R. Soc. Lond. Ser. B Biol. Sci. 371:20150292. doi: $10.1098 /$ rstb.2015.0292

Knappe, A., Hör, S., Wittmann, S., and Fickenscher, H. (2000). Induction of a novel cellular homolog of interleukin-10, AK155, by transformation of $\mathrm{T}$ lymphocytes with herpesvirus saimiri. J. Virol. 74, 3881-3887. doi: 10.1128/ JVI.74.8.3881-3887.2000
Konradsen, J. R., Nordlund, B., Levänen, B., Hedlin, G., and Linden, A. (2016). The cytokine interleukin-26 as a biomarker in pediatric asthma. Respir. Res. 17:32. doi: 10.1186/s12931-016-0351-6

Larochette, V., Miot, C., Poli, C., Beaumont, E., Roingeard, P., Fickenscher, H., et al. (2019). IL-26, a cytokine with roles in extracellular DNA-induced inflammation and microbial defense. Front. Immunol. 10:204. doi: 10.3389/ fimmu.2019.00204

Meller, S., Di Domizio, J., Voo, K. S., Friedrich, H. C., Chamilos, G., Ganguly, D., et al. (2015). TH17 cells promote microbial killing and innate immune sensing of DNA via interleukin 26. Nat. Immunol. 16, 970-979. doi: 10.1038/ ni.3211

Miot, C., Beaumont, E., Duluc, D., Le Guillou-Guillemette, H., Preisser, L., Garo, E., et al. (2014). IL-26 is overexpressed in chronically HCV-infected patients and enhances TRAIL-mediated cytotoxicity and interferon production by human NK cells. Gut 64, 1466-1475. doi: 10.1136/gutjnl-2013-306604

Patel, S., and Akhtar, N. (2017). Antimicrobial peptides (AMPs): The quintessential 'offense and defense' molecules are more than antimicrobials. Biomed. Pharmacother. 95, 1276-1283. doi: 10.1016/j.biopha.2017.09.042

Poli, C., Augusto, J. F., Dauvé, J., Adam, C., Preisser, L., Larochette, V., et al. (2017). IL-26 confers proinflammatory properties to extracellular DNA. J. Immunol. 198, 3650-3661. doi: 10.4049/jimmunol.1600594

Scala, E., Di Caprio, R., Cacciapuoti, S., Caiazzo, G., Fusco, A., Tortorella, E., et al. (2019). A new $T$ helper 17 cytokine in hidradenitis suppurativa: antimicrobial and proinflammatory role of interleukin-26. Br. J. Dermatol. 181, 1038-1045. doi: 10.1111/bjd.17854

Sheikh, F., Baurin, V. V., Lewis-Antes, A., Shah, N. K., Smirnov, S. V., Anantha, S., et al. (2004). IL-26 signals through a novel receptor complex composed of IL-20 receptor 1 and IL-10 receptor 2. J. Immunol. 172, 2006-2010. doi: 10.4049/jimmunol.172.4.2006

Silhavy, T. J., Kahne, D., and Walker, S. (2010). The bacterial cell envelope. Cold Spring Harb. Perspect. Biol. 2:a000414. doi: 10.1101/cshperspect.a000414

Weber, B. S., Harding, C. M., and Feldmann, M. F. (2016). Pathogenic Acinetobacter: from the cell surface to infinity and beyond. J. Bacteriol. 198, 880-887. doi: 10.1128/JB.00906-15

Woetmann, A., Alhede, M., Dabelsteen, S., Bjarnsholt, T., Rybtke, M., Nastasi, C., et al. (2018). Interleukin-26 (IL-26) is a novel anti-microbial peptide produced by $\mathrm{T}$ cells in response to staphylococcal enterotoxin. Oncotarget 9, 1948119489. doi: 10.18632/oncotarget.24603

Yeaman, M., Yount, N. Y., Waring, A. J., Gank, K. D., Kupferwasser, D., Wiese, R., et al. (2007). Modular determinants of antimicrobial activity in platelet factor-4 family kinocidins. Biochim. Biophys. Acta 1768, 609-619. doi: 10.1016/j. bbamem.2006.11.010

Yount, N. Y., Gank, K. D., Xiong, Y. Q., Bayer, A. S., Pender, T., Welch, W. H., et al. (2004). Platelet microbicidal protein 1: structural themes of a multifunctional antimicrobial peptide. Antimicrob. Agents Chemother. 48, 4395-4404. doi: 10.1128/AAC.48.11.4395-4404.2004

Zasloff, M. (2002). Antimicrobial peptides of multicellular organisms. Nature 415, 389-395. doi: 10.1038/415389a

Conflict of Interest: The authors declare that the research was conducted in the absence of any commercial or financial relationships that could be construed as a potential conflict of interest.

Publisher's Note: All claims expressed in this article are solely those of the authors and do not necessarily represent those of their affiliated organizations, or those of the publisher, the editors and the reviewers. Any product that may be evaluated in this article, or claim that may be made by its manufacturer, is not guaranteed or endorsed by the publisher.

Copyright (c) 2021 Hansen, Maschkowitz, Podschun and Fickenscher. This is an open-access article distributed under the terms of the Creative Commons Attribution License (CC BY). The use, distribution or reproduction in other forums is permitted, provided the original author(s) and the copyright owner(s) are credited and that the original publication in this journal is cited, in accordance with accepted academic practice. No use, distribution or reproduction is permitted which does not comply with these terms. 